\title{
The Effects of 2.4-Dichlorophenoxyacetic Acid Upon the Growth of Roots
}

\author{
By Hayashi ONo*
}

\section{小野 林：根の発育に及梳す2.4-D. の影響}

In the course of the experiments concerning the effects of 2.4-Dichlorophenoxyacetic acid (2.4-D.) upon the germination of seeds, the author frequently observed various abnormal or weak developments of the roots of germinated seeds. The main object of the present communication is to elucidate the effect of 2.4-D. upon the growth of root in several plants.

\section{Experimental Methods.}

Solutions of 2.4-D. in varying concentrations ranging from 2 to $0.00001 \%$ were prepared and $\mathrm{pH}$ was adjusted to 7.0. Lemna sp., Zea Mays L., and Oryza sativa L. were used as test materials. In the case of Lemna plant, which is composed of three or four individuals chaining one another, the individuals were separated, the

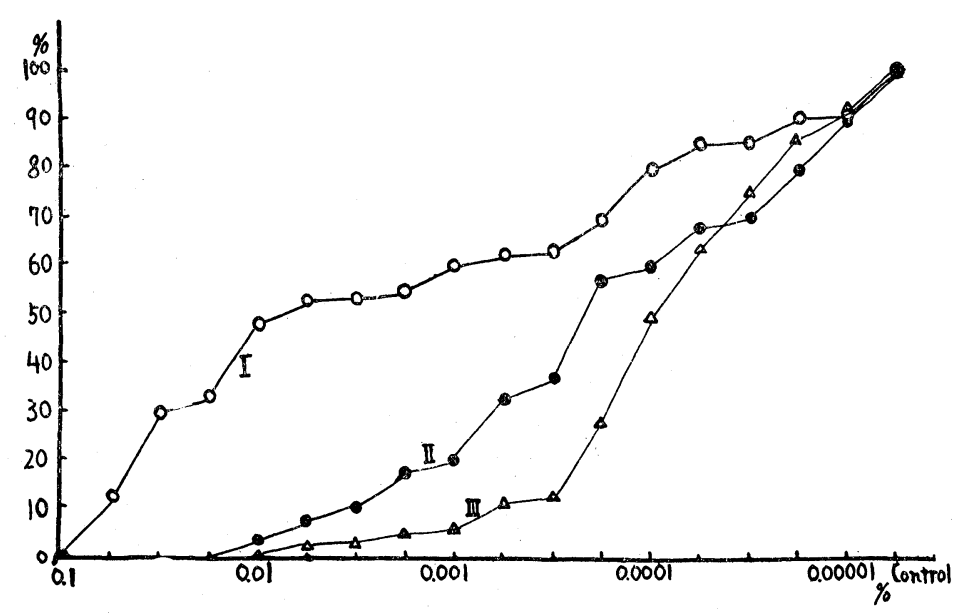

Fig. 1. The effects of 2.4-D. on the growth of Lemna sp. Abscissa indicates the concentration (\%) of $2.4-\mathrm{D}$. and ordinate indicates the rate of growth compared with those of the control represented $100 \%$.

I. Number of individual bodies.

II. Number of the roots formed.

III. Length of roots.

\footnotetext{
* Biological Institute, Faculty of Culture, University of Kyushu.
} 
roots were cut off and the materials were cultured at room temperature in the solutions containing 2.4-D. in varying concentrations. After ten days the number of the individuals as well as the number and growth of roots were examined. In thc case of Zea Mays and Oryza sativa, the seeds were introduced in Petri dishes with filter paper at the bottom and the solution of 2.4-D. was added till the seeds were half immersed. Seven days after, the dishes were placed either in the light or in the dark room (at room temperature) and the rate of germination, the length of coleoptiles and the number as well as the length of the roots formed were examined.

\section{Results.}

a) Lemna sp. As will be seen from Fig. 1, complete death of Lemna plant was brought about when 2.4-D. was supplied in concentrations higher than $0.1 \%$. The formation and the growth of roots were observed when the concentration of 2.4-D. was lower than $0.01 \%$. However, even in the highly diluted solution, such as $0.00001 \%$, the increase in the individual bodies, the formation and the growth of roots were somewhat smaller than those of the control. Thus it is evident that the

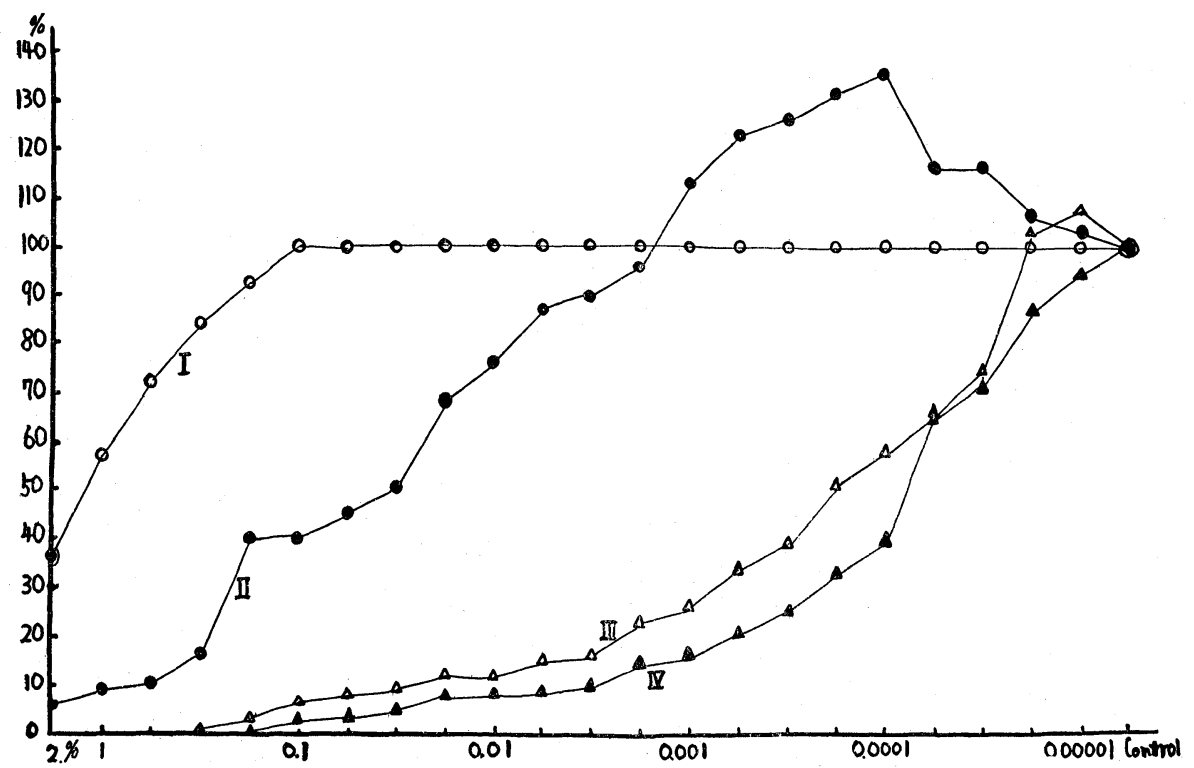

Fig. 2. The effects of 2.4-D. on the germination and early growth of Zea Mays L. Abscissa indicates the concentration of 2.4-D. and ordinate indicates rate of germination and early growth compared with those of the control represented $100 \%$.

I. Rate of germination.

II. Length of coleoptiles.

III. Number of the roots formed.

IV. Length of roots. 
formation and the growth of roots are always more strongly affected by 2.4-D. than the growth of individual bodies. In $0.01 \%$ solution, for instance, the rate of the increase in the individuals was $48 \%$, whereas the rate of root formation and that of root growth were only 3 and $0.9 \%$ respectively.

b) Zea Mays. As can be seen from Fig. 2, the rate of germination was very low when the concentration of 2.4-D. was higher than $0.2 \%$, but reaches the normal value $(100 \%)$ when it falls less than $0.1 \%$. As a whole, the formation and the growth of roots were more markedly inhibited by 2.4-D. than the growth of coleoptile. The growth of coleoptiles was promoted by 2.4-D. at concentrations less than $0.001 \%$, and the maximum promotion was observed at $0.0001 \%$. In dilute solutions, many short and small roots were formed and the growth rate of which was comparatively lower. The results obtained both in the light and in the dark were the same, but in the light room the roots and the coleoptiles formed were shorter and starker.

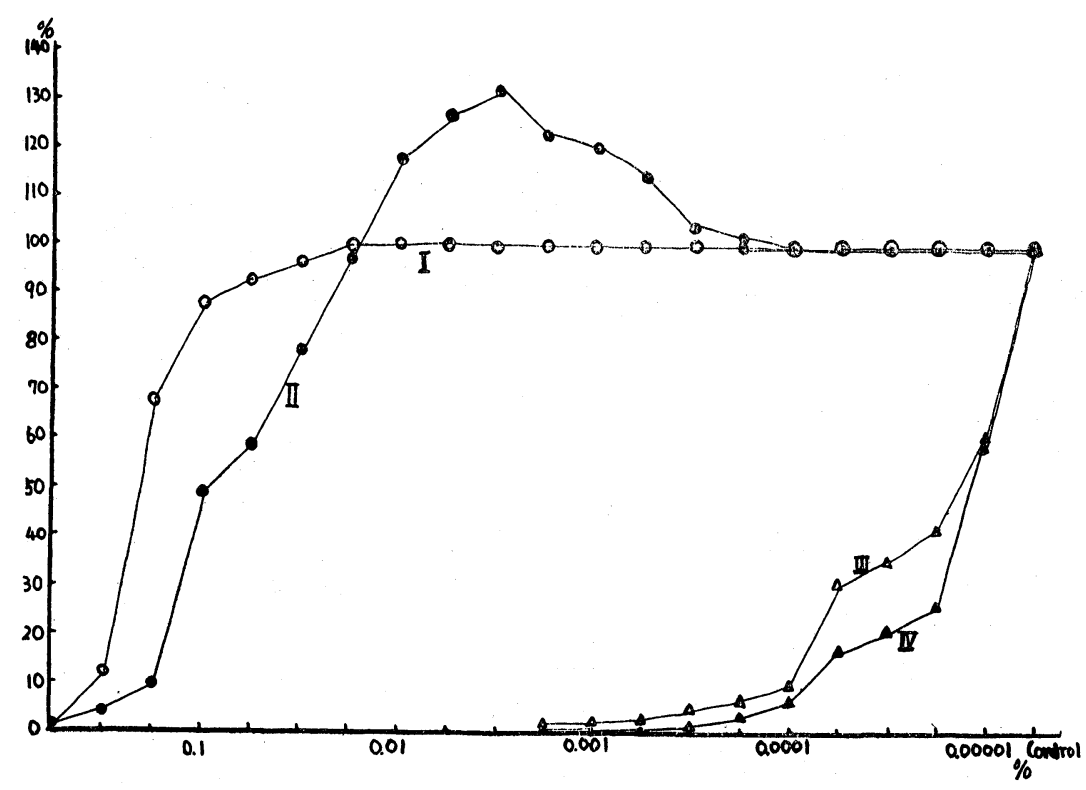

Fig. 3. The effects of 2.4-D. on the germination and early growth of Oryza sativa $\mathrm{L}$. Abscissa indicates the concentration of 2.4-D. and ordinate indicates rate of germination and early growth as compared with those in the control represented $100 \%$.

I. Rates of germination.

II. Length of coleoptiles.

III. Number of the roots formed.

IV. Length of roots. 
c) Oryza sativa. As can be seen from Fig. 3, the rate of germination and of growth of coleoptile in Oryza sativa was similar to that of Zea Mays in principle, but the mode of the growth of roots differed markedly from that of the latter. The growth of coleoptiles was maximum in the presence of $0.005 \% 2.4-\mathrm{D}$, , but the growth of roots was never observed at this concentration, indicating that the root is more sensitive to $2.4-\mathrm{D}$. than the coleoptile. The sensitivity of the growth of root was more marked in Oryza than in Zea. For example, in $0.0001 \%$ solution, the relative values of the number and the length of root in Zea were 58 and $48 \%$ respectively, whereas those in Oryza were 10 and $6 \%$ respectively.

As mentioned above, the growth of root of three plant species tested was more strongly inhibited by $2.4-\mathrm{D}$. than the other parts of the body.

\section{References.}

1. Bein, M.: Chem. Abst. 48: 7372. 1948. 2. Dhillon, A. S.: Bot. Gaz. 112: 199. 1951. 3. Haglorg, A. E.: Science 111 : 91. 1950. 4. Hagen, C.E.: Science 110 : 116. 1949. 5. 川田信 一郎： 科学 $21 ： 332.1951 .6$. 川上 繁：農業及園芸 26：467. 1951. 7. 笠原安夫：農業及園芸 23：503-506. 1948. 8. 笠原安夫：農業及園芸 24：515．1949． 9. 笠原安夫：農業及園芸 25：415. 1950. 10. 笠原安夫：農学研究 $38: 27$. 1949. 11. Low, C. H.：Science 105 : 287. 1947. 12. Mitchelland, J. W.: Science 106 : 266. 1947. 13. Murray, M.B.: Bot. Gaz. 110: 404-426. 1949. 14. Nance, J. F.： Science 109 : 174. 1949. 15. 小野 林：農業及園芸 25：685. 1950. 16. Sell, H. M.： Plant Physiol. 24 : 215. 1949. 17. Smith, G.F.: Plant Physiol. $23:$ 83. 1948. 18. 竹松哲夫：農業 及園芸 24 ：593. 1949, 19. Tullis, E.C.： Science 111：90. 1950，20. Weintrauf, R. L.： Science 495. 1950. 21. Went, F. R.: Science 111: 579. 1950. 22. Wolf, D. E.: Bot. Gaz. 112: 188. 1951.

摘 要

トウモロコシ，稻，ウキクサ科植物の根の発育に反ほす 2.4-D. の影響について 実験した。 ウキクサ科植物は個体の增加に比較して根の形成及び発育は著しく 2.4-D. で阻害され, 特に高 濃度に於て著しい。トウモロコシ，稻については種子の発芽時の子葉鞘と根の発育の関係を見 た。何れも根の発育は著しく阻害され，それに比較して子葉䩪の発育は $0.01 \% \sim 0.0001 \%$ 前後 に於て促進される。稻はトゥモロコシに比較して根の発育は更に阻害され，0.001\% に於て始め て根の発育が見られる。何れの場合に於ても，根は個体の発育や子葉鞘の発育に比較して 2.4-D. に対する感受性が强く, 特に高濃度に於て阻害される。 